(c) American Dairy Science Association, 2004.

\title{
Environmental Influences on Claw Horn Lesions Associated with Laminitis and Subacute Ruminal Acidosis in Dairy Cows*
}

\author{
N. B. Cook, K. V. Nordlund, and G. R. Oetzel \\ School of Veterinary Medicine, \\ University of Wisconsin Madison 53706-1102
}

\begin{abstract}
The environment may influence the onset of laminitis and associated claw horn lesions of dairy cows by exacerbating changes in the hoof triggered by events at parturition, onset of subacute ruminal acidosis, or claw horn growth and wear and ground reaction forces on different walking surfaces. Environmental risk factors for laminitis and associated claw horn lesions include feed bunk space and design, pen layout, overstocking, heat stress, stall use behavior, and exposure to concrete and other types of walking surfaces. New evidence suggests that cow environment may be the final determinant of the degree of laminitis and lameness observed on dairy farms.
\end{abstract}

(Key words: laminitis, claw horn lesion, environmental risk factor, subacute ruminal acidosis)

Abbreviation key: SARA = subacute ruminal acidosis.

\section{INTRODUCTION}

Several studies in North America, the United Kingdom, and Scandinavia report a wide range in the prevalence of lameness in dairy cattle between herds, typically of the order of 0 to $55 \%$ of the herd affected (Wells et al., 1993; Clarkson et al., 1996; Cook, 2003a; Manske et al., 2002; Whay et al., 2002). This variation may be due to a combination of many factors, including breed types surveyed, genetic selection, conformation characteristics, nutrition and feeding practices, amount of milk production, manure handling systems, presence or absence of certain types of infectious disease, and factors related to the environment in which dairy cows are kept.

Received July 10, 2003.

Accepted November 24, 2003.

Corresponding author: N. B. Cook; e-mail: nbcook@wisc.edu.

*Presented at a symposium titled "Laminitis in Dairy Cattle" at the ADSA-ASAS Joint Annual Meeting, June 2003, Phoenix, AZ.
There is a growing body of evidence to suggest that the dairy cow's environment, including factors related to where she may rest, eat, drink, socialize, and milk, may be the final determinant of the degree of lameness. The role that the environment has to play on North American dairy farms in triggering and exacerbating an important cause of lameness, namely laminitis and its associated claw horn lesions, will be the subject of this discussion.

Terminology related to laminitis has become confusing in recent years, in light of the possibility that lesions of the claw horn traditionally associated with laminitis may have alternative routes of causation (Webster, 2001). This paper will use the term laminitis when reference is made to the condition related to ruminal acidosis, and the term claw horn lesion to describe lesions of the claw, such as sole hemorrhage, ulceration, and white line disease.

\section{THE PREVALENCE OF LAMINITIS AND ASSOCIATED CLAW HORN LESIONS}

Several studies have reported on the importance of claw horn lesions associated with laminitis in dairy herds. They may be divided into those that determine the prevalence of lesions in all cows and those that determine lesion prevalence in lame cows only.

Using a system of sole scoring originally developed at the VI Symposium of Diseases of the Ruminant Digit in Liverpool (1990), Smilie et al. (1996) found claw horn lesions in each of 13 free stall herds and in $34.8 \%$ of claws of first lactation heifers when examinations were made from $60 \mathrm{~d}$ before parturition to $>60$ $\mathrm{d}$ after. Bergsten (1994) reported that sole hemorrhage affected $>80 \%$ of cows in 22 herds, and, in a more recent survey of 101 Swedish herds (predominantly housed in tie stalls), Manske et al. (2002) found claw horn lesions in $64.7 \%$ of claws of 4899 cows across a range of parities.

When only lame cows were considered, claw horn lesions were responsible for between 35 and $60 \%$ of the lameness recorded in two studies on free stallhoused herds with summer grazing in the United 
Table 1. Prevalence of foot lesions in lame dairy cows adapted from four studies utilizing different housing systems.

\begin{tabular}{|c|c|c|c|c|}
\hline Unit of measurement & $\begin{array}{l}\text { Murray et al. } \\
\text { (1996) }\end{array}$ & $\begin{array}{l}\text { Kossaibati and } \\
\text { Esslemont (2000) }\end{array}$ & $\begin{array}{l}\text { Warnick et al. } \\
(2001)\end{array}$ & Cook (2004) \\
\hline Country (state) of origin & UK & UK & USA (NY) & USA (WI) \\
\hline Herds, no. & 37 & 50 & 2 & 10 \\
\hline Laminitic cause & $\begin{array}{l}\text { (\% total lame } \\
\text { diagnoses) }\end{array}$ & $\begin{array}{l}\text { (\% total lame } \\
\text { diagnoses) }\end{array}$ & $\begin{array}{l}\text { (\% lame diagnoses; } \\
\text { mean of } 2 \text { farms) }\end{array}$ & $\begin{array}{l}\text { (\% lame diagnoses } \\
\text { (mean of } 10 \text { herds) }\end{array}$ \\
\hline Sole hemorrhage & 8 & 2 & NR & 6 \\
\hline White-line disease & 22 & 9 & 9 & 10 \\
\hline Double sole & 2 & NR & NR & NR \\
\hline \multicolumn{5}{|l|}{ Infectious cause } \\
\hline $\begin{array}{l}\text { Digital dermatitis } \\
\text { (heel warts) }\end{array}$ & 8 & 20 & 32 & 57 \\
\hline Foot rot & 5 & 13 & 11 & 1 \\
\hline
\end{tabular}

Kingdom (Murray et al., 1996; Kossaibati and Esslemont, 2000). Warnick et al. (2001) found claw horn lesions responsible for 23.3 and $33.1 \%$ of lameness events in 2 US herds housed in free stalls. In a survey of 1155 lameness treatments on 10 Wisconsin dairy herds involving cattle housed in either tie stall or free stall housing all year round (Cook, 2004), claw horn lesions were responsible for $36.2 \%$ of the treatments (Table 1). These studies suggest that across a wide range of housing conditions, claw horn lesions are responsible for 23 to $60 \%$ of lameness in dairy cows. However, these data may underestimate the extent of the problem. When surveys include both lame and non-lame cows, the prevalence of claw horn lesions is even higher (Manske et al., 2002).

\section{ENVIRONMENTAL EFFECTS-MECHANISMS AND SITES OF ACTION}

The evidence supporting the view that laminitis is, at least in part, a nutritional disease has been reviewed by Vermunt (2000). Subacute ruminal acidosis (SARA) may be one trigger factor for laminitis. Nordlund and Garrett (1994) suggest that this disease is a common and serious problem on many US dairy herds. Nutritional factors other than SARA may also be involved. Heifers reared on a diet based on wet, fermented grass silage suffered a higher rate of white line and sole lesions both pre- and postpartum compared with heifers reared on a diet based on dry, unfermented concentrate fed from weaning until 1 mo prior to calving (Offer et al., 2001, 2003). These results sug- gest a residual effect of prepartum feeding beyond parturition.

Although development of laminitis can be nutritionally based, there is a growing body of evidence to suggest that environmental factors play a significant role in influencing the rate and development of lesions (Bergsten and Frank, 1996a; Webster, 2001). Environmental factors appear to operate in 3 main areas by acting 1) to influence lying and standing behavior, which may worsen claw horn lesions initially triggered by changes at parturition or by the onset of SARA; 2) to promote the onset of SARA during lactation, thereby triggering the processes that may lead to laminitis and claw horn lesions, and 3) to influence claw horn growth and wear and ground reaction forces on different walking surfaces

\section{Environmental Interaction with Parturition and SARA}

Bergsten and Frank (1996a) attempted to investigate the effects of diet and tie stall flooring on claw horn lesions in 60 Swedish Friesian heifers in early pregnancy. The prevalence of sole hemorrhage was not increased by exposure to concrete compared with rubber mat stalls or by the feeding of $6.5 \mathrm{~kg} / \mathrm{d}$ of grain (50\% barley, $50 \%$ oats) compared with a low $(0.4 \mathrm{~kg})$ grain diet. In contrast, a similar combination of stall flooring and dietary manipulation produced significant effects during the periparturient period ( $3 \mathrm{wk}$ before to $13 \mathrm{wk}$ after calving). Those heifers kept on concrete and fed a high concentrate ration had the 
worst sole hemorrhage scores (Bergsten and Frank, 1996b). These results suggest an interaction between calving, changes in diet and changes in the environment in which first lactation heifers are kept.

Recent studies have attempted to differentiate housing effects from other potential causes of claw horn lesions. Webster (2001) noted that claw lesion scores worsened after calving in heifers housed either on straw bedded packs or in free stalls from 4 wk before to $24 \mathrm{wk}$ after calving. Lesions were more severe in heifers housed in free stalls than in heifers on a straw bedded pack and were exacerbated by the feeding of low DM feed (25\% DM). Livesey et al. (1998) also reported that white line and sole hemorrhage scores in heifers postpartum were exacerbated by free stall housing compared with housing in straw yards. Feeding a high concentrate diet also had a measurable effect on claw lesions.

These data suggest that systemic changes at first calving in heifers appear to be one trigger factor for claw horn lesions, setting in motion a chain of events that are influenced by environmental and dietary factors. Hirst et al. (2002) demonstrated that cows suffering lameness during the first lactation are more susceptible to lameness in subsequent lactations, especially because of claw horn lesions during the second lactation. Thus, events at first parturition are an important area of lameness research. The possibility that claw horn lesions may be reduced simply by improving the housing of heifers at this critical time is extremely significant and, if true, is a goal that is easily achievable on many farms.

Subacute ruminal acidosis is likely another potential trigger for the onset of laminitis and associated claw horn lesions. Environmental, dietary, and management factors that promote the onset of SARA provide another route for exacerbating a herd problem. The impact of SARA on claw health may be mediated via gelatinoproteases, which elongates collagen fibers and loosens the connective tissues of the hoof, similar to the pathway described at parturition by Tarlton et al. (2002). Australian work has suggested an alternative method of metalloproteinase activation and subsequent laminitis, using an equine hoof explant model. Mungall et al. (2001) showed that streptococcal pyrogenic exotoxin B (SpeB) released from Streptococcus bovis might activate metalloproteinase- 2 in a dosedependent manner and lead to the separation of equine lamellar explants. These results demonstrate a putative link between damage to the integrity of the hoof and $S$. bovis, an organism known to proliferate in the rumen during shifts to high grain feeding (Tajima et al., 2001). Studies need to be repeated in cattle to confirm this link.
Seemingly different causes of claw horn lesions apparently share common pathways. For example, either SARA or events at parturition may elongate the collagen within the suspensory apparatus of the third phalanx, which then increases its mobility and likelihood of sinking within the horny claw capsule (Lischer et al., 2002). This initial insult may then be exacerbated by a compromised cow environment, in which cows spend excessive time standing (either in stalls with all 4 feet on the platform, 'perching' in the stall with only the front 2 feet on the platform, or standing in alleys and holding areas) or insufficient time lying. Excessive time spent in postures involving increased weight bearing on the foot may further weaken the connection between the pedal bone and the claw wall. The end result is claw horn lesions at the sole surface, but the causes were multiple and interrelated.

\section{The Interaction of the Claw with Floor Surfaces}

Bazeley and Pinsent (1984) were among the first to suggest that claw horn lesions are more severe when cows are housed on concrete walking surfaces in intensively managed dairy herds. Greenough and Vermunt (1991) reported that excessive time spent standing on hard surfaces might predispose the hoof to claw horn lesions. Biomechanical insults at rest and during locomotion on hard surfaces, caused by ground reaction forces at the claw-floor interface, have been suggested as a reason why lesions are most commonly found on the outer claw of the hind foot, which is often overgrown (Russell et al., 1982; Clarkson et al., 1996; Le Fevre et al., 2001, van der Tol et al., 2002). This accelerated growth of horn in the hind foot outer claw and subsequent overloading is believed to result from irritation of the corium, which is caused by greater changes in weight distribution during locomotion for the outer claw compared with the inner claw in dairy cows (Toussaint Raven et al., 1985). Paulus and Nuss (2002) have recently suggested that anatomical differences in the length of the medial and lateral hind digit may also contribute to the overloading of the outer claw.

Where claw horn quality is compromised, effects of poor flooring surfaces may be compounded. The structure of the white line and the quality of the horn produced is weakened at calving time (Kempson and Logue, 1993) and during laminitis (Mulling, 2002) and may result in increased likelihood of white line disease when the claw is subjected to roughened surfaces.

Toe ulcers or abscesses have reportedly become more common in dairy cows (Kofler, 1999; Van Amstel and Shearer, 2000), and environmental factors appear 


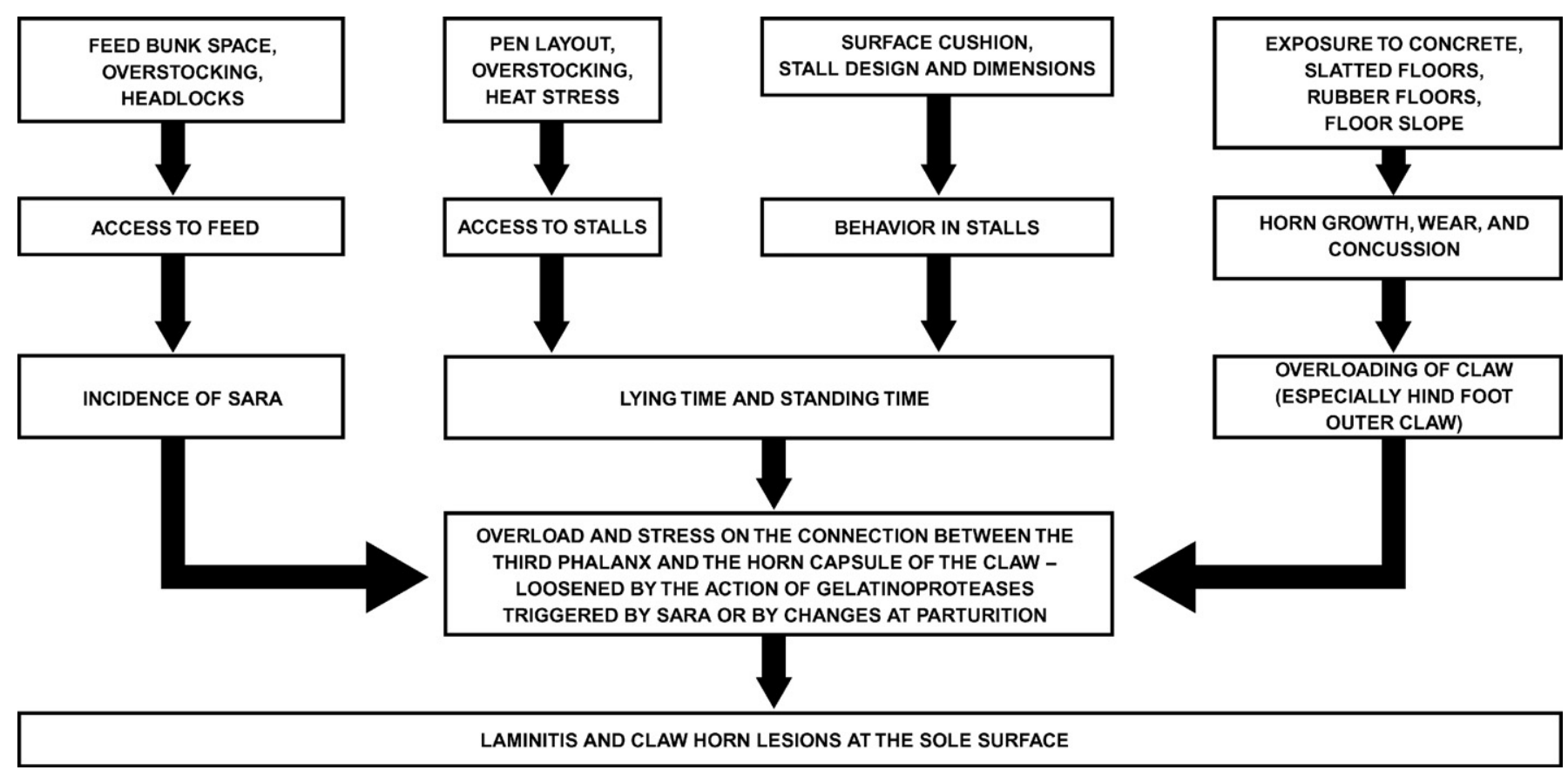

Figure 1. The influence of environmental factors on the incidence of subacute ruminal acidosis, cow lying and standing behavior, and claw horn growth, wear and concussion believed to be involved in the development of laminitis and claw horn lesions. SARA = Subacute ruminal acidosis.

to be of importance in explaining the increase in prevalence. The effect of mechanical abrasion and excessive wear caused by rough concrete surfaces and increased walking distances in modern dairy facilities may be exacerbated by the production of inferior quality horn caused by laminitis, which increases the rate of wear (Van Amstel and Shearer, 2000). The situation may be further worsened by over-trimming attributable to inappropriate use of grinding discs (Kofler, 1999) or an attempt to balance claws that are already excessively worn. The development and use of different types of floor surfaces that reduce ground reaction forces and prevent excessive concussion of the outer claw of the hind foot and wear of the sole is currently a subject of growing research interest (Jungbluth et al., 2003; Vokey et al., 2003).

\section{ENVIRONMENTAL FACTORS-EFFECTS AND OUTCOMES}

The discussion so far has described the 3 basic mechanisms that may trigger claw horn lesions-namely events at parturition, the possible metabolic changes associated with SARA, and excessive claw horn wear and concussion. In this next section, we will shift the discussion to environmental factors that have a practical influence on these basic mechanisms. These factors are displayed in Figure 1 and include access to feed, access to stalls, cow activity in stalls relative to lying and standing behavior, and type of flooring surface. The discussion will also highlight the importance of documenting outcomes in outliers; socially subordinate cows that undergo changes in behavior are often undetected by examination of group mean data.

\section{Access to Feed}

High yielding dairy cows eat for approximately 3 to $5 \mathrm{~h} / \mathrm{d}$ and consume approximately 9 to 14 meals (Grant and Albright, 2001). A primary goal of feeding in many dairy herds is to ensure that cows have access to feed when they want to eat. Ad libitum intake implies uninterrupted access to feed for 21 to $22 \mathrm{~h} / \mathrm{d}$ with about $5 \%$ or more feed refusal. Otherwise, dairy cattle may over-eat following a period of feed deprivation. It is clear, however, that there are many situations on a farm that arise that make this target difficult to achieve.

Experimental induction of SARA. Subacute ruminal acidosis has been experimentally induced in beef steers by withholding feed for $12 \mathrm{~h}$ (Reinhardt et al., 1997) or $24 \mathrm{~h}$ (Goad et al., 1998) followed by access to large amounts of grain. A lesser degree of SARA was induced in dairy cattle by restricting TMR intake early in the morning and then feeding a mixture of finely ground wheat and barley $2 \mathrm{~h}$ later (Keunen et 
al., 2002). Following SARA induction, cows altered their diet by selecting more long hay, presumably in an attempt to attenuate SARA (Keunen et al., 2002). It appears that cows have inherent protective mechanisms to regulate their own ruminal $\mathrm{pH}$ via eating patterns. Therefore, these mechanisms must have been overcome when SARA occurs in the field, perhaps when several factors that limit intake converge in time and space.

Such an event could happen when cows have limited access to feed because of overstocking or pen design, social factors preempt established meal patterns, feed delivery is irregular, cows are moved to new pens or held in headlocks for extended periods, or diets are suddenly changed. These factors likely interact with nutritional risk factors (low fiber diets, high DMI, sorting of long particles, etc.), which ultimately increase the likelihood of SARA.

Feed bunk space and design. The central argument for feed bunk space allowance and design is related to the belief that space is not required for all of the cows in a pen to feed at the same time, provided a well-mixed TMR is available throughout the day. Proponents of this argument cite work that suggests that cows do not maximize occupancy of the feed bunk for most of the day. Friend et al. (1977) found that mean DMI for a group of 12 cows was unaffected across a range of feed bunk allowances from 0.5 to $0.1 \mathrm{~m}$ per cow, although time spent at the bunk was reduced at $0.1 \mathrm{~m}$. Menzi and Chase (1994) examined bunk activity in 2 high-yielding dairy herds with 3-row pen designs containing 88 to 90 cows per pen. They noted that maximum feed bunk use was limited to brief periods during the day, for not more than $15 \mathrm{~min}$ at a time, particularly when fresh feed arrived and immediately after milking. A critical amount of bunk space per cow of only $0.2 \mathrm{~m}$ has been suggested (Grant and Albright, 1995). Typical barn designs exceed this critical bunk space allowance, but there is a wide range depending on rows of stalls and stocking rates. In a typical 3-row pen, stocked at one cow per stall $(100 \%)$, there is 0.46 $\mathrm{m}$ of bunk space per cow. In contrast, in a typical 2row pen similarly stocked, there is $0.74 \mathrm{~m}$ of bunk space per cow (Brouk, 2003). Even at $140 \%$ stocking in a 2-row pen, feed line space is $>0.46 \mathrm{~m}$.

Those that argue for the provision of more bunk space point out that the majority of studies fail to take into consideration that reduced access to feed will have an impact on individual cows within a group in different ways. High social rank cows may be completely unaffected, whereas low social rank cows may struggle to feed when they wish. Although no statistics were performed, dominance behavior was observed at the bunk when feed-line space was $0.1 \mathrm{~m}$ per cow (Friend et al., 1977). Olofsson (1999) investigated cow competition at a TMR feeding station. With increasing competition, the manner in which cows ate was affected; the number of meals increased, eating times were shorter, consumption rate increased, and number of displacements from the station also increased. Dominant cows were less affected than subordinate cows, and the latter were observed to stand and lie down more around milking times when eating was normally preferred. Similarly, Batchelder (2000) noted that in an overstocked pen with headlocks, some cows went to lie down in stalls rather than feed at the bunk, suggesting that there were modifications of behavior patterns in some animals.

Feed bunk design may also potentially limit access to feed. Batchelder (2000) compared headlocks to a post and rail system in a 2-row pen stocked at 100 and $130 \%$ relative to stalls. Use of headlocks appeared to decrease DMI by 3 to $5 \%$ depending on stocking density. Brouk et al (2003), however, did not find an effect of headlocks on DMI or performance on cattle previously trained to use them. It is not known whether headlocks affect eating patterns or the risk for SARA, but some degree of training prior to calving appears to be beneficial.

In a rare attempt to link feed access with lameness, Leonard et al. (1998b) reported on the results of a study comparing 2 groups of 20 heifers: one group with $0.55 \mathrm{~m}$ of feed space and the other with $0.30 \mathrm{~m}$ of feed space per animal. Heifers at $0.30 \mathrm{~m}$ spent longer time feeding each day, and significantly more aggressive encounters were observed in this group. No overall effects on claw health were observed initially but, 3 mo after the experiment, heifers that engaged in more aggressive encounters had worse claw-horn lesion scores than did those that avoided such encounters.

More research is needed to further investigate access to feed in large groups of cattle fed a TMR. Consumption patterns rather than total DMI appear to be important in the development of SARA. Clearly, we need to consider the effect of reduced feed access on low-ranking cows that may be forced to alter daily activity patterns and feed at the bunk only after dominant cows have sorted the fresh feed. These data may well lead us to recommend more feed bunk allowance than is commonly seen in modern barn constructions.

\section{Access to Stalls}

Stall access may be a limiting factor in free stallhoused herds because it may impact lying times and stall usage. Access may be influenced by interactions between social rank and pen layout, overstocking, heat stress, and a variety of other management factors. 
Social factors. It is clear that cows have a daily time budget for activities. If this time budget is stressed, cows tend to contract other activities to maintain a relatively fixed amount of lying. Metz (1985) showed that following a 3-h period of lying and feeding deprivation, cows chose to compensate for their loss of lying time in preference to feeding. Management issues such as very long turn times in the parlor or locking cows in head locks for prolonged periods may change cow behavior over the subsequent hours. Cows can compensate, provided that these challenges are not too frequent. First lactation heifers may struggle to compensate for dramatic changes in their environment. When first exposed to free stalls in a competitive situation, heifers may lie down for as little as $6.25 \mathrm{~h} / \mathrm{d}$ (Singh et al., 1993a). Reduction in stall use after calving may explain the severe claw horn lesions often observed in trials where heifers are moved from pasture to free stall housing within a few weeks of parturition (Kempson and Logue, 1993; Bergsten and Frank, 1996b).

Social factors operating within a group may determine where a cow may lie down. Both Natzke et al. (1982) and Gaworski et al. (2003) identified a trend for reduced use of stalls at the end of a row. In the latter study, it was noted that stalls in a 3-row pen design with direct access from the feed alley were occupied $41 \%$ more than stalls accessed from the far alley. These differences may be explained by social structure. It is possible that cows low in the pen hierarchy may not travel to the rear alley to lie down for fear of encountering a high-ranking cow. Thus, it would seem that a pen layout where at least some stalls are accessible from the feed alley would be preferable. Note that in a 2-row tail-to-tail pen design, all of the cows must pass through a 3 - to $4-\mathrm{m}$ wide alley opening before accessing a stall. Current recommendations for the number of stalls between crossovers between the feed alley and the rear alley in such a pen may therefore be inadequate to optimize stall access.

Overstocking. Overstocking may also impact stall access and use. Overcrowding has been found to decrease lying times in free stalls. Friend et al. (1977) found that mean daily lying time was only significantly reduced in a pen with 12 lactating cows when stocking density reached $200 \%$ (2 cows per stall). In a series of studies monitoring cow behavior in groups of 15 to 20 lactating dairy cows, Wierenga and Hopster (1990) compared stall use behavior at 3 levels of overstocking (125, 133.3, and $155 \%$ with respect to stalls) with behavior at normal stocking density (100\%). Interestingly, these reseasrchers were able to identify high- and low-ranking individuals in the groups. The behavior of high-ranking cows was largely unaffected by overstocking, but behavior of low-ranking individuals was significantly altered, even at only $125 \%$ overstocking. A significant reduction in lying time for these individuals during the night was reported at all levels of overstocking, which was compensated by increased lying in the evening up to $155 \%$, but at this level of overstocking, the compensation mechanism was overwhelmed. This study clearly demonstrated the importance of detecting effects on outlier cows rather than evaluating only group means. Significant differences would only have been apparent at $155 \%$ overstocking if the effect on low-ranking cows had not been explored.

Leonard et al. (1996) found that daily lying times averaged $7.5 \mathrm{~h} / \mathrm{d}$ in a group of autumn-calving heifers housed at a stocking density of $200 \%$ immediately after calving. Lying times varied widely from 2.7 to $11.9 \mathrm{~h} / \mathrm{d}$. Cows that consistently lay down for $\leq 5 \mathrm{~h} / \mathrm{d}$ were identified and classified as the short-lying group. Claw horn lesion score was greater in the short-lying group compared with medium- and long-lying groups, but not until 4 mo after calving, indicating that prolonged periods of short lying times were required to observe lesions visible on the sole. Four of 7 animals with short lying times $(<5$ to $<7.5 \mathrm{~h} / \mathrm{d}$ depending on month of recording) developed lameness compared with only 1 of 10 long-lying cows (>7.75 to $10 \mathrm{~h} / \mathrm{d}$ depending on month of recording).

Once again, studies of limited duration relying solely on group means to determine the outcome fail to completely explain the complex social interactions and cow compensatory mechanisms taking place in barns with limited access to stalls. The long-term health effects of stocking pens at $>100 \%$ of stall capacity have yet to be fully explored. The lag time observed between the environmental stressor and the observation of visible claw horn lesions at the sole surface is of importance. Current estimates suggest that the total renewal of sole horn and progress of horn from the corium to the sole surface takes approximately 3 to 4 mo (Schmid, 1995). Experiments designed to determine the impact of an environmental change on claw health must therefore involve claw monitoring for a period of at least 3 to 5 mo after the challenge.

Heat stress behavior. Heat stress modifies cow behavior and may increase the risk for laminitis and claw horn lesions. Overton et al. (2002) noted that the proportion of the cows lying was reduced as ambient temperature increased during the day in a California dairy with sand free stalls. Schultz (1984) has shown that the percentage of cows standing increases with increasing ambient temperature. Overton et al. (2002) suggested that cows might stand under fans in the feed alley (there were no fans over the stalls in the study described) to improve heat dissipation. Thus, 
even in a situation with well-designed stalls, heat stress may limit the amount of time spent in them and ultimately place cows at increased risk of laminitis and claw horn lesions.

\section{Standing and Lying Behavior in Stalls}

A recent study by Phillips and Rind (2001) suggested that cows at pasture, unencumbered by stall designs that inhibit standing and lying, typically have daily lying times of 10.9 to $11.5 \mathrm{~h} / \mathrm{d}$. A growing number of studies based on the behavior of cows in stalls suggest a significant relationship between standing and lying times and lameness.

On 2 similar farms with nearly identical stall designs and rations, Colam-Ainsworth et al. (1989) elegantly demonstrated that a claw horn lesion problem in early lactation in first lactation heifers on one farm was associated with a dramatic difference in the amount of straw bedding being used on the concrete stall surfaces. The problem farm used $75 \%$ less bedding, and cows on this farm also spent a greater time standing in alleys and perching with the 2 front feet on the stall platform and the 2 rear feet in the alley. An increase in the amount of bedding being used appeared to alleviate the problem. Bergsten (1994) reported an improvement in sole hemorrhage scores in one herd where stalls had been fitted with rubber mats. Thus, cow comfort and use of stalls appears to have a significant impact on claw horn lesion development.

The mechanics of rising and lying for the cow are complex (Nordlund and Cook, 2003), and there appears to be an interesting interaction between lunging inhibition because of stall design and rising surface. Haley et al. (2000) found that cows were more reluctant to change position from lying to standing when restricted in tie stalls. Krohn and Munksgaard (1993) noted that cows are more frequently interrupted when attempting to lie down in tie stalls than when attempting to do so in loose housing. Haley et al. (2001) found that lying times increased in tie stalls from 10.4 $\mathrm{h} / \mathrm{d}$ on concrete to $12.2 \mathrm{~h} / \mathrm{d}$ on a mattress stall base. Cows lay down less frequently, but for longer periods, on concrete, suggesting that they were reluctant to perform the actual process of standing and lying.

For the cow to rise on her rear legs safely, she must transfer weight over the front knees, creating a point of balance, which requires the cow's head to almost touch the ground in an area referred to as the 'bob zone.' Stall designs that inhibit this lunge and bob movement of the head may reduce stall usage by creating fear of slippage of the rear feet on the stall surface because of inadequate weight transfer. This fear ex- plains the reluctance to change position on a stall surface that increases the risk of slipping.

Whatever the divider design, improved lying times have been reported on more cushioned surfaces (Wandel et al., 2002). These surfaces may also supply more traction and thereby reduce the fear associated with lying and rising in a compromised stall design. Hultgren (2001) reported on the change in cow behavior when comparing cows kept in tie stalls with a rubberized slatted surface with cows on a typical stall fitted with a rubber mat and loose bedding. The rubber slat floor appeared to improve surface traction and allow rising and lying without risk of slipping. These rubberized slat floors were associated with a lower risk of claw horn lesions.

Stall surface preference. A concrete stall surface with a small quantity of finely chopped bedding material can no longer be considered an acceptable surface for a dairy cow to lie down upon. A wide range of surface options are now available for both free stalls and tie stalls. These include hard rubber mats; mattresses consisting of rubber crumbs, foam, air, and water cushioning; and deep, loosely bedded stalls typically using sand, soil, or sawdust. Existing data on cow preferences for these different stall surfaces are inconclusive. Cows preferred to lie down on deep, loosely bedded stalls compared with mats or mattresses in some studies (Gebremedhin et al., 1985; Tucker et al., 2003; Wagner-Storch et al., 2003), but not in others (Manninen et al., 2002).

Stall preference studies, where cows have a choice of occupying a stall with a variety of different surfaces, must be interpreted with care. They represent an artificial situation that may be affected by an animal's prior experience, location of the stall surface type in the pen, or adaptation during the study. Preference for a certain type of stall surface should not imply inadequacy of another type of surface. For example, cows previously exposed to sawdust beds in one study preferred sawdust over a mattress and sand; those previously exposed to sand beds also preferred sawdust initially, but increasingly preferred sand stalls later on (Tucker et al., 2003). Ambient temperature has also been shown to affect stall preference for mattresses compared with sand (Lay et al., 2002; WagnerStorch et al., 2003).

Although lying preference was similar between sand and cushioned mattress free stalls, Wagner-Storch et al. (2003) reported higher overall occupancy (including lying and standing) rates in stalls with mattresses. They suggested that cows prefer to spend non-lying time standing on mattress stalls rather than on concrete alleys, which may carry some potential benefits. However, data from 30 Wisconsin dairy herds (Cook, 
2003) suggest that lameness is more prevalent in herds using mattress stalls than in herds using sand stalls. A stall-usage index, measured as the proportion of cows in stalls that were standing either completely in or one-half in stalls at $1 \mathrm{~h}$ before milking, was significantly greater in herds with mattress stalls compared with sand stalls, which related to lameness prevalence (Cook, 2002a,b). These data suggest that daily standing time on mattress stalls may be longer than on sand stalls, and this might have a negative effect on claw health. Research is ongoing in this area in an attempt to fully understand stall use behavior in sand and mattress free stall herds and to determine its relative significance to hoof health.

Stall design. The effect of other aspects of stall design on cow behavior has received much recent attention (Anderson, 2002). Gaworski et al. (2003) reported that neck rail location is an important determinant of how cows behave in free stalls. Comparing neck rail heights of 1 and $1.27 \mathrm{~m}$ above the stall surface, they found increased standing time in the stalls with the greater height. Moving the neck rail from 1.7 to $1.52 \mathrm{~m}$ from the rear curb changed the type of standing behavior, with an increase in perching and a reduction in standing with all 4 feet on the platform at $1.52 \mathrm{~m}$. Neck rail location did not affect lying behavior. Nordlund et al. (2001) reported on the effects of a lower divider rail that was mounted too high to allow side lunging in a stall that was too short to allow forward lunging. Herd losses involved an increased removal rate for trauma caused by stall entrapment and a reduction in milk quality.

Aspects of stall design such as lack of surface cushion, low divider rails $(<0.34 \mathrm{~m})$, limited lunge space, and high rear curbs $(>0.16$ to $0.2 \mathrm{~m})$ have all been related to an increased risk of lameness or claw horn lesions (Leonard et al., 1994; Philipot et al., 1994; Faull et al., 1996). Such data are difficult to interpret, however. They apply to designs of stall dividers that may not be commonplace in some countries and generally fail to consider interactions between stall surface and the ability of the cow to rise and lie in the stall free of obstructions. Few studies have documented a stall design problem linked with a change in cow behavior and then determined the effect on the risk for laminitis and lesions of the claw horn. Leonard et al. (1994) presented data from 43 heifers housed in a free stall barn with access to 2 stall designs pre- and postpartum. The first allowed for side lunging and was bedded with a rubber mat, and the second was a more restrictive divider design with a concrete stall surface. The authors noted reduced lying and increased periods spent perching in heifers housed in the pen with the more restrictive divider style and firmer stall surface.
These heifers suffered significantly worse claw hemorrhage scores and an increased rate of clinical lameness in the 2 mo after calving compared with heifers in the less restrictive stall with greater surface cushion. Correlation between reduced lying behavior and worsening claw health was observed in heifers in the more comfortable stalls.

The effect of social rank. Galindo and Broom (2000) have confirmed that low-ranking individuals spend less time lying and more time standing still and perching in free stalls than middle- and high-ranking cows. Hierarchy position was determined using an index of displacement based on mutual stall evictions between individuals. Excessive time spent perching in stalls was identified as a significant risk factor for interdigital and heel lesions. Increased total time standing ( $>45 \%$ of the time in the pen) significantly increased sole lesions and lameness cases. The survival time to lameness for low-ranking cows was significantly shorter than for high-ranking animals, with more than $60 \%$ suffering clinical lameness within the 25 -wk period of the study. In a follow up study, Galindo et al. (2000) further examined standing behavior in low-ranking individuals in a group of 40 lactating cows housed in stalls with a restrictive design. Low-rank cows stood still in alleys and perched in free stalls for significantly longer than high-rank cows. Importantly, those researchers were able to track behavior patterns as individuals became lame during the study period. Compared with those individuals that remained sound, the lame cows were of lower rank and stood for significantly longer perching in stalls. Mean time standing still in alleys was not significantly different.

The mechanism by which stall behavior influences the risk for laminitis appears to be due either to a reduction in lying time and/or an increase in abnormal standing behavior in stalls. In particular, perching behavior, with 2 feet on the stall and 2 feet in the alley, appears to be a significant risk factor for lameness.

\section{Flooring Surfaces}

Benefits from different floor types may come from improved resting times in the case of pasture or strawbedded loose housing or from a reduction in horn wear and ground reaction forces at the claw-floor interface, particularly when comparison with concrete is made.

Type of surface. Singh et al. (1993b) documented improved lying times on straw yards compared with free stalls, but also indicated that hoof health benefits may accrue from time spent standing on a softer surface. Recently, Somers at el. (2003) compared herds with straw yards with those utilizing slatted concrete floors and solid concrete floors. Cows on straw yards 
exhibited the lowest levels of claw disorders compared with similar levels on slatted and concrete floors. Unfortunately, types of stall design and surface were not controlled in this study.

The use of slatted floors in cow barns is commonplace in Europe and used to some degree in North America. Stefanowska et al. (2002) described a cow preference study with two types of barn floors: grooved concrete and a concrete slatted-floor. Perhaps surprisingly, the cows spent more time on the slatted floor compartment. Attempts to improve the cushion of slatted floors are being made; Jungbluth et al. (2003) described the beneficial effects of rubber-coated slats in the alley compared with concrete-slatted floors. The rubber surface reduced the severity of wall and sole lesions. There was no difference in horn wear between the surfaces, but differences in cow behavior were observed: step length was greater, walking speed was faster, and the incidence of caudal licking (with one hind leg raised) was increased on the rubber surface.

Rubberized floor surfaces in the feed alley have become commonplace in new barn constructions in North America. Vokey et al. (2001) compared rubber feed bunk alley surface with concrete in association with combinations of sand, mattress, and concrete free stall surfaces. The overall effect of rubber floor surfaces was unclear, however. For several indices of hoof health, the sand stall-rubber alley combination outranked other combinations consistently. Vokey et al. (2003) also found that the lowest net growth of the dorsal hoof wall and the greatest maintenance of balance between the inner and outer claws were found with a combination of rubber alley floors with sand free stalls. Cows kept on concrete had higher net growth rates and the greatest imbalance between the claws, creating a situation of overloading in the outer claw of the hind foot.

In contrast, Leonard et al. (1998a) reported on a small-scale trial looking at the potential benefits of rubber flooring at the feedbunk. Interestingly, animals appeared to select to stand on the matting partly in preference to using the stalls. Free stall utilization was reduced, and stall standing behavior was altered. Claw horn lesion scores were worse in the group with access to matting. The authors expressed caution in interpreting the results in a small group of cows, but raised concern regarding use of mats in combination with a stall design that they viewed as suboptimal. However, Fregonesi et al. (2002) reported that cows on rubber flooring spent more time standing inactive and less time lying in a similar study. It would therefore appear that in certain situations where stall design and comfort is compromised, the addition of rub- ber matting in alleys may increase standing time and may actually be detrimental to hoof health.

Floor slope. Little work has been done on the effect of floor slope on lameness. Vokey et al. (2003) reported on standing for prolonged periods on sloped surfaces and showed a beneficial effect on claw health from standing for 45 to $90 \mathrm{~min}$ on a $5 \%$ slope, rising from tail to head. This slope was designed to simulate standing time in the holding area prior to milking. This experiment failed to simulate the wearing effect of standing and walking on sloped concrete, and the benefits observed were probably due to drainage of moisture away from the claws rather than any effect on claw wear.

Further research is required in the development of improved walking surfaces for dairy cattle, both in terms of cushion and slope. Providing cushion or a gentle slope may be beneficial in some situations, but it appears that rubber feed alleys combined with compromised stall designs might have a negative impact on hoof health.

\section{CONCLUSIONS}

Changes associated with first parturition, SARA, and excessive claw horn wear and concussion have been suggested as trigger factors for laminitis and claw horn lesions in dairy cows. Environmental factors that inhibit access to feed and stalls and influence cow behavior in stalls have been discussed. Such factors affect growth and wear of claws and forces acting upon them during standing and walking between lying sessions. Key changes in stall use behavior have been linked to the onset of claw horn lesions. Daily lying times of only 5 to $7 \mathrm{~h} / \mathrm{d}$ appear to be a significant risk factor. However, in studies where cows have lying times of around $10 \mathrm{~h} / \mathrm{d}$ or more, stall standing behavior, including perching (with 2 feet on the stall platform and 2 feet in the alley), appears to be a quite separate and important risk factor.

Future research must target specific behaviors in modern free stall facilities that are being built in North America to determine cow activity patterns in 60 to 90 cow pens and beyond. Research related to access to feed and stalls must consider outliers, lowranking individuals whose daily activity is dramatically changed by overstocking and other management factors. Much progress is being made in the area of stall design and comfort, and we must continue our efforts to create environments that allow all cows in a herd to eat when they want to eat, lie down when they want to rest, drink when they are thirsty, and socialize without fear or stress. If we provide for these freedoms of behavior, the dairy cow will undoubtedly 
reward us with reduced laminitis and claw horn lesions, increased milk yield, and greater overall health and longevity.

\section{REFERENCES}

Anderson, N. 2002. Observations on cow comfort using 24 hour time lapse video. Pages 27-34 in Proc. 12th Int. Symp. Lameness in Ruminants, Orlando, FL.

Batchelder, T. L. 2000. The impact of head gates and overcrowding on production and behavior patterns of lactating dairy cows. Pages 325-330 in Proc. Conf. Dairy Housing and Equipment Systems: Managing and Planning for Profitability, NRAES -129, Camp Hill, PA. Natural Resources, Agric., Eng. Serv., Ithaca, NY.

Bazeley, K., and P. J. N. Pinsent. 1984. Preliminary observations on a series of outbreaks of acute laminitis in dairy cattle. Vet. Rec. 115:619-622.

Bergsten, C. 1994. Haemorrhages of the sole horn of dairy cows as a retrospective indicator of laminitis: An epidemiological study. Acta Vet. Scand. 35:55-66.

Bergsten, C., and B. Frank. 1996a. Sole hemorrhages in tied heifers in early gestation as an indicator of laminitis: Effects of diet and flooring. Acta Vet. Scand. 37:375-382.

Bergsten, C., and B. Frank. 1996b. Sole hemorrhages in tied primiparous cows as an indicator of periparturient laminitis: Effects of diet, flooring and season. Acta Vet. Scand. 37:383-394.

Brouk, M. J. 2003. Managing facilities to maximize dry matter intake. Pages 15-27 in Proc. Ontario Assoc. Bov. Pract. Mtg., Guelph, ON, Canada.

Brouk, M. J., J. F. Smith, and J. P. Harner, III. 2003. Effect of feedline barrier on feed intake and milk production of dairy cattle. Pages 192-195 in Proc. 5th Int. Dairy Housing Conf., Fort Worth, TX. Am. Soc. Agric. Eng., St. Joseph, MI.

Clarkson, M. J., D. Y. Downham, W. B. Faull, J. W. Hughes, F. J. Manson, J. B. Merritt, R. D. Murray, W. B. Russell, J. E. Sutherst, and W. R.Ward. 1996. Incidence and prevalence of lameness in dairy cattle. Vet. Rec. 138:563-567.

Colam-Ainsworth, P., G. A. Lunn, R. C. Thomas, and R. G. Eddy. 1989. Behaviour of cows in cubicles and its possible relationship with laminitis in replacement dairy heifers. Vet. Rec. 125:573576.

Cook, N. B. 2002a. Lameness prevalence and the effect of housing on 30 Wisconsin dairy herds. Pages $325-327$ in Proc. 12th Int. Symp. Lameness in Ruminants, Orlando, FL.

Cook, N. B. 2002b. The influence of barn design on dairy cow hygiene, lameness and udder health. Pages 97-103 in Proc. 35th Annu. Conf. Am. Assoc. Bovine. Pract., Stillwater, OK.

Cook, N. B. 2003. The prevalence of lameness in a selection of Wisconsin dairy herds utilizing different types of housing and stall surface. J. Am. Vet. Med. Assoc. 223:1324-1328.

Cook, N. B. 2004. Lameness treatment rates in Wisconsin Dairy Herds. Pages 50-51 in Proc. 13th Int. Symp. Lameness in Ruminants, Maribor, Slovenia.

Faull, W. B., J. W. Hughes, M. J. Clarkson, D. Y. Downham, F. J. Manson, J. B. Merritt, R. D. Murray, W. B. Russell, J. E. Sutherst, and W. R. Ward. 1996. Epidemiology of lameness in dairy cattle: The influence of cubicles and indoor and outdoor walking surfaces. Vet. Rec. 139:130-136.

Fregonesi, J. A., F. Flower, T. Vittie, C. B. Tucker, and D. M. Weary. 2002. Rubber flooring affects behavior of dairy cows, especially animals with hoof injuries. J. Dairy Sci. 85(Suppl. 1):28 (Abstr.).

Friend, T. H., C. E. Polan, and M. L. McGilliard. 1977. Freestall and feed bunk requirements relative to behavior, production and individual feed intake in dairy cows. J. Dairy Sci. 60:108-116.

Galindo, F., and D. M. Broom. 2000. The relationships between social behaviour of dairy cows and the occurrence of lameness in three herds. Res. Vet. Sci. 69:75-79.

Galindo, F., D. M. Broom, and P. G. G. Jackson. 2000. A note on possible link between behaviour and the occurrence of lameness in dairy cows. Appl. Anim. Behav. Sci. 67:335-341.
Gaworski, M. A., C. B. Tucker, D. M. Weary, and M. L. Swift. 2003. Effects of stall design on dairy cattle behavior. Pages 139-146 in Proc. Dairy Housing Conf., Fort Worth, TX. Am. Soc. Agric. Eng., St Joseph, MI.

Gebremedhin, K. G., C. O. Cramer, and H. J. Larsen.1985. Preference of dairy cattle for stall options in freestall housing. Trans. Am. Soc. Agric. Eng. 28:1637-1640.

Goad, D.W., C. L. Goad, and T. G. Nagaraja. 1998. Ruminal microbial and fermentative changes associated with experimentally induced subacute acidosis in steers. J. Anim. Sci. 76:234-241.

Grant, R. J., and J. L. Albright. 1995. Feeding behavior and management factors during the transition period in dairy cattle. J. Anim. Sci. 73:2791-2803.

Grant, R. J., and J. L. Albright. 2001. Effect of animal grouping on feeding behavior and intake of dairy cattle. J. Dairy Sci. 84 (E. Suppl):E156-E163.

Greenough, P. R., and J. J. Vermunt. 1991. Evaluation of subclinical laminitis in a dairy herd and observations on associated nutritional and management factors. Vet. Rec. 128:11-17.

Haley, D. B., J. Rushen, and A. M. de Passille. 2000. Behavioural indicators of cow comfort: Activity and resting behaviour of dairy cows in two types of housing. Can. J. Anim. Sci. 80: 257-263.

Haley, D. B., A. M. de Passille, and J. Rushen. 2001. Assessing cow comfort: effect of two types and two tie stall designs on the behaviour of lactating dairy cows. Appl. Anim. Behav. Sci. 71:105-117.

Hirst, W. M., R. D. Murray, W. R. Ward, and N. P. French. 2002. A mixed-effects time to event analysis of the relationship between first lactation lameness and subsequent lameness in dairy cows in the UK. Prev. Vet. Med. 54:191-201.

Hultgren, J. 2001. Observational and experimental studies of the influence of housing factors on the behaviour and health of dairy cows. Ph.D. Diss., Swedish Univ. Agric. Sci., Uppsala, Sweden.

Jungbluth, T., B. Benz, and H. Wandel. 2003. Soft walking areas in loose housing systems for dairy cows. Pages 171-177 in Proc. Dairy Housing Conf., Fort Worth, TX. Am. Soc. Agric. Eng., St. Joseph, MI.

Kempson, S. A., and D. N. Logue. 1993. Ultrastructural observations of hoof horn from dairy cows: Changes in the white line during the first lactation. Vet. Rec. 132:524-527.

Keunen, J. E., J. C. Plaizier, L. Kyriazakis, T. F. Duffield, T. M. Widowski, M. I. Lindinger, and B. W. McBride. 2002. Effects of a subacute ruminal acidosis model on the diet selection of dairy cows. J. Dairy Sci. 85:3304-3313.

Kofler, J. 1999. Clinical study of toe ulcer and necrosis of the apex of the distal phalanx in 53 cattle. Vet. J. 157:139-147.

Kossaibati, M. A., and R. J. Esslemont. 2000. The incidence of lameness in 50 dairy herds in England. Pages 160-162 in Proc. XI Int. Symp. Disorders of the Ruminant Digit, Parma, Italy. Fondazione Iniziative Zooprofilattiche e Zootechniche, Brescia, Italy.

Krohn, C. C., and L. Munksgaard. 1993. Behaviour of dairy cows kept in extensive or intensive environments II: Lying and lying down behaviour. Appl. Anim. Behav. Sci. 37:1-16.

Lay, Jr., D. C., L. L. Timms, and R. Thoreson. 2002. Effects of stall surface on occupancy and postural changes in dairy cows. J. Dairy Sci. 85(Suppl. 1):28. (Abstr.).

Le Fevre, A. M., D. N. Logue, J. E. Offer, I. McKendrick, and G. Gettinby. 2001. Correlations of measurements of subclinical claw horn lesions in dairy cattle. Vet. Rec. 148:135-138.

Leonard, F. C., J. M. O'Connell, and K. J. O'Farrell. 1994. Effect of different housing conditions on behaviour and foot lesions in Friesian heifers. Vet. Rec. 134:490-494.

Leonard, F. C., J. M. O'Connell, and K. J. O'Farrell. 1996. Effect of overcrowding on claw health in first-calved Friesian heifers. Br. Vet. J. 152:459-472.

Leonard, F. C., J. Crilly, and K. J. O'Farrell. 1998a. Efficacy of currently recommended control measures for lameness in dairy cows. Teagasc Project Rep. 3981. Teagasc, Moorepark Research Center, Fermoy, Ireland.

Leonard, F. C., I. Stienezen, and K. J. O'Farrell. 1998b. Overcrowding at the feeding area and effects on behavior and claw health in Friesian heifers. Pages 40-41 in Proc. 10th Int. Symp. Lameness in Ruminants, Lucerne, Switzerland. 
Lischer, C. J., P. Ossent, M. Raber, and H. Geyer. 2002. Suspensory structures and supporting tissues of the third phalanx of cows and their relevance to the development of typical sole ulcers (Rusterholz ulcers). Vet. Rec. 151:694-698.

Livesey, C. T., T. Harrington, A. M. Johnston, S. A. May, and J. A. Metcalf. 1998. The effect of diet and housing on the development of sole haemorrhage, white line haemorrhage and heel horn erosion in Holstein heifers. Anim. Sci. 67:9-16.

Manninen, E., A. M. de Passille, J. Rushen, M. Norring, and H. Saloniemi. 2002. Preferences of dairy cows kept in unheated buildings for different kind of cubicle flooring. Appl. Anim. Behav. Sci. 75:281-292.

Manske, T., J. Hultgren, and C. Bergsten. 2002. Prevalence and interrelationships of hoof lesions and lameness in Swedish dairy cows. Prev. Vet. Med. 54:247-263.

Menzi, W., and L. E. Chase. 1994. Feeding behavior of cows housed in freestall barns. Pages 829-831 in Dairy Systems for the 21st Century. Am. Soc. Agric. Eng., St. Joseph, MI.

Metz, J. H. M. 1985. The reaction of cows to a short-term deprivation of lying. Appl. Anim. Behav. Sci. 13:301-307.

Mulling, C. K. W. 2002. Theories on the pathogeneisis of white line disease-An anatomical perspective. Pages 90-96 in Proc. 12th Int. Symp. Lameness in Ruminants, Orlando, FL.

Mungall, B. A , M. Kyaw-Tanner, and C. C. Pollitt. 2001. In vitro evidence for a bacterial pathogenesis of equine laminitis. Vet. Microbiol. 79:209-223.

Murray, R. D., D. Y. Downham, M. J. Clarkson, W. B. Faull, J. W. Hughes, F. J. Manson, J. B. Merritt, W. B. Russell, J. E. Sutherst, and W. R. Ward. 1996. Epidemiology of lameness in dairy cattle: Description and analysis of foot lesions. Vet. Rec. 138:586-591.

Natzke, R. P., D. R. Bray, and R. W. Everett. 1982. Cow preference for freestall surface material. J. Dairy Sci. 65:146-153.

Nordlund, K., S. Peek, T. Bennett, K. Emery, and J. Gaska. 2001. Inches from disaster: Mastitis and injury problems associated with freestall modifications in a large dairy herd. Pages 296-300 in Proc. 2nd Int. Symp. Mastitis and Milk Quality, Vancouver, Canada. Natl. Mastitis Council, Madison, WI.

Nordlund, K. V., and N. B. Cook. 2003. A flowchart for evaluating dairy cow freestalls. Bov. Pract. 37:89-96.

Nordlund, K. V., and E. F. Garrett. 1994. Rumenocentesis: A technique for collecting rumen fluid for the diagnosis of subacute rumen acidosis in dairy herds. Bov. Pract. 28:109-116.

Offer, J. E., E. J. Fisher, S. A. Kempson, and D. N. Logue. 2001. The effect of feeding grass silage in early pregnancy on claw health during first lactation. Vet. J. 161:186-193.

Offer, J. E., K. A. Leach, S. Brocklehurst, and D. N. Logue. 2003. Effect of forage type on claw horn lesion development in dairy heifers. Vet. J. 165:221-227.

Olofsson, J. 1999. Competition for total mixed diets fed for ad libitum intake using one or four cows per feeding station. J. Dairy Sci. 82:69-79.

Overton, M. W., W. M. Sischo, and D. A. Moore. 2002. Using time lapse video photography to assess dairy cattle lying behavior in a freestall barn. J. Dairy Sci. 85:2407-2413.

Paulus, N., and K. Nuss. 2002. Claw measurements at defined sole thickness. Pages 428-430 in Proc. 12th Int. Symp. Lameness in Ruminants, Orlando, FL.

Philipot, J. M., P. Pluvinage, I. Cimarosti, P. Sulpice, and F. Bugnard. 1994. Risk factors of dairy cow lameness associated with housing conditions. Vet. Res. 25:244-248.

Phillips, C. J. C., and M. I. Rind. 2001. The effects on production and behaviour of mixing uniparous and multiparous cows. J. Dairy Sci. 84:2424-2429.

Reinhardt, C. D., R. T. Brandt, K. C. Behnke, A. S. Freeman, and T. P. Eck. 1997. Effect of steam-flaked sorghum grain density on performance, mill production rate, and subacute acidosis in feedlot steers. J. Anim. Sci. 75:2852-2857.

Russell, A. M., G. J. Rowlands, S. R. Shaw, and A. D. Weaver. 1982. Survey of lameness in British dairy cattle. Vet. Rec. 111:155-160.

Schmid, M. 1995. Der einfluss von biotin auf die klauenhornqualitat beim rind. DVM Thesis, Univ. Zurich, Switzerland.
Schultz, T. A. 1984. Weather and shade effects on cow corral activities. J. Dairy Sci. 67:868-873.

Singh, S. S., W. R. Ward, K. Lautenbach, J. W. Hughes, and R. D. Murray. 1993a. Behaviour of first lactation and adult dairy cows while housed and at pasture and its relationship with sole lesions Vet. Rec. 133:469-474.

Singh, S. S., W. R. Ward, K. Lautenbach, and R. D. Murray.1993b. Behaviour of lame and normal dairy cows in cubicles and in a straw yard. Vet. Rec. 133:204-208.

Smilie, R. H., K. H. Hoblet, W. P. Weiss, M. L. Eastridge, D. M. Rings, and G. L. Schnitkey. 1996. Prevalence of lesions associated with subclinical laminitis in first-lactation cows from herds with high milk production. J. Am. Vet. Med. Assoc. 208:1145-1451.

Somers, J. G. C. J., K. Frankena, E. N. Noordhuizen-Stassen, and J. H. M. Metz. 2003. Prevalence of claw disorders in dutch dairy cows exposed to several floor systems. J. Dairy Sci. 86:2082-2093.

Stefanowska, J., D. Swierstra, J. V. Van den Berg, and J. H. M. Metz. 2002. Do cows prefer a barn compartment with a grooved or slotted floor? J. Dairy Sci. 85:79-88.

Tajima, K., R. I. Aminov, T. Nagamine, H. Matsui, M. Nakamura, and Y. Benno. 2001. Diet-dependent shifts in baterial population of the rumen revealed in real-time PCR. Appl. Environ. Microbiol. 67:2766-2774.

Tarlton, J. F., D. E. Holah, K. M. Evans, S. Jones, G. R. Pearson, and A. J. F. Webster. 2002. Biomechanical and histopathological changes in the support structures of bovine hooves around the time of calving. Vet. J. 163:196-204.

Toussaint Raven, E., R. T. Halstra, and D. J. Peterese. 1985. Cattle Foot Care and Claw Trimming. Farming Press, Ipswich, UK.

Tucker, C. B., D. M. Weary, and D. Fraser. 2003. Effects of three types of freestall surfaces on preferences and stall usage by dairy cows. J. Dairy Sci. 86:521-529.

Van Amstel, S. R., and J. K. Shearer. 2000. Toe abscess: a serious cause of lameness in the U.S. dairy industry. Pages 212-214 in Proc. XI Int. Symp. Disorders of the Ruminant Digit, Parma, Italy. Fondozione Iniziative e Zooprofilattiche, Brescia, Italy.

Van der Tol, P. P. J., J. H. M. Metz, E. N. Noordhuizen-Stassen, W. Back, C. R. Braam, and W. A. Weijs. 2002. The pressure distribution under the bovine claw during square standing on a flat substrate. J. Dairy Sci. 85:1476-1481.

Vermunt, J. J. 2000. Risk factors of laminitis-An overview. Pages 34-45 in Proc. III Int. Conf. on Bovine Lameness, Parma, Italy. Fondazione Iniziative Zooprofilattiche e Zootechniche, Brescia, Italy.

Vokey, F. J., C. L. Guard, H. N. Erb, and D. M. Galton. 2001. Effects of alley and stall surfaces on indices of claw and leg health in dairy cattle housed in a freestall barn. J. Dairy Sci. 84:2686-2699.

Vokey, F. J., C. L.Guard, H. N. Erb, and D. M. Galton. 2003. Observation on flooring and stall surfaces for dairy cattle housed in a freestall barn. Pages 165-170 in Proc. Dairy Housing Conf., Fort Worth, TX. Am. Soc. Agric. Eng., St. Joseph, MI.

Wagner-Storch, A. M., R. W. Palmer, and D. W. Kammel. 2003. Factors affecting stall use for different freestall bases. J. Dairy Sci. 86:2253-2266.

Wandel, H., T. Jungbluth, and B. Benz. 2002. Cow comfort in loose house systems. Page 313 in Proc. 12th Int. Symp. Lameness in Ruminants, Orlando, FL.

Warnick, L. D., D. Janssen, C. L. Guard, and Y. T. Grohn. 2001. The effect of lameness on milk production in dairy cows. J. Dairy Sci. 84:1988-1997.

Webster, A. J. F. 2001. Effects of housing and two forage diets on the development of claw horn lesions in dairy cows at first calving and in first lactation. Vet. J. 162:56-65.

Wells, S. J., A. M. Trent, W. E. Marsh, and R. A. Robinson. 1993. Prevalence and severity of lameness in lactating dairy cows in a sample of Minnesota and Wisconsin dairy herds. J. Am. Vet. Med. Assoc. 202:78-82.

Whay, H. R., D. C. J. Main, L. E.Green, and A. J. F. Webster. 2002. Farmer perception of lameness prevalence. Pages 355-358 in Proc. 12th Int. Symp. Lameness in Ruminants, Orlando, FL.

Wierenga, H. K., and H. Hopster.1990. The significance of cubicles for the behaviour of dairy cows. Appl. Anim. Behav. Sci. 26:309-337. 